\title{
Corpus Callosum Lipoma
}

National Cancer Institute

\section{Source}

National Cancer Institute. Corpus Callosum Lipoma. NCI Thesaurus. Code C5438.

A rare benign adipose tissue neoplasm of the corpus callosum. 